\title{
Pengaruh Profitabilitas dan Kepemilikan Manajerial pada Kebijakan Dividen dengan Likuiditas sebagai Variabel Moderasi
}

\author{
Ni Wayan Yunisari ${ }^{1}$ \\ Ni Made Dwi Ratnadi ${ }^{2}$ \\ ${ }^{1}$ Fakultas Ekonomi dan Bisnis Universitas Udayana (Unud), Bali, Indonesia \\ email: yunisariwyn@gmail.com/Telp : +6287762232858 \\ ${ }^{2}$ Fakultas Ekonomi dan Bisnis Universitas Udayana (Unud), Bali, Indonesia
}

\begin{abstract}
ABSTRAK
Penelitian ini bertujuan untuk memperoleh bukti empiris pengaruh profitabilitas pada kebijakan dividen, pengaruh kepemilikan manajerial pada kebijakan dividen, pengaruh profitabilitas pada kebijakan dividen dengan likuiditas sebagai variabel moderasi dan pengaruh kepemilikan manajerial pada kebijakan dividen dengan likuiditas sebagai variabel moderasi. Populasi penelitian adalah perusahaan manufaktur yang terdaftar di Bursa Efek Indonesia. Teknik penentuan sampel menggunakan metode purposive sampling dengan kriteria perusahaan manufaktur yang membagikan dividen periode 2012-2016 dan diperoleh 193 pengamatan. Teknik analisis data menggunakan Moderated analysis regression.Berdasarkan hasil analisis ditemukan bahwa profitabilitas berpengaruh positif pada kebijakan dividen. Hal ini menunjukkan bahwa apabila profitabilitas perusahaan meningkat menyebabkan jumlah dividen yang dibayar meningkat. Kepemilikan manajerial tidak berpengaruh pada kebijakan dividen. Likuiditas tidak memoderasi pengaruh profitabilitas dan kepemilikan manajerial pada kebijakan dividen.

Kata kunci : kebijakan dividen, kepemilikan, likuiditas dan profitabilitas.
\end{abstract}

\begin{abstract}
This study aims to obtain empirical evidence of the effect of profitability on dividend policy, the effect of managerial ownership on dividend policy, the effect of profitability on dividend policy with liquidity as a moderating variable and the effect of managerial ownership on dividend policy with liquidity as a moderating variable. The population of this research is manufacturing company listed on the Indonesia Stock Exchange. The technique of determining sample using purposive sampling method with criteria manufacturing companies that distribute dividend period 2012-2016 and obtained 193 observations. Data analysis technique using Moderated analysis regression. Based on the results of the analysis found that profitability has a positive effect on dividend policy. This shows that if the profitability of the company increases, the amount of paid dividend increases. Managerial ownership has no effect on dividend policy. Liquidity does not moderate the effect of profitability and managerial ownership on dividend policy.

Keyword : dividend policy, ownership, liquidity and profitability
\end{abstract}

\section{PENDAHULUAN}

Kebijakan dividen merupakan keputusan perusahaan dalam menentukan besarnya

laba yang diperoleh perusahaan yang akan dialokasikan untuk dividen atau 
dijadikan saldo laba ditahan. Kebijakan dividen menjadi perhatian banyak pihak seperti pemegang saham, kreditor maupun pihak eksternal lain yang memiliki kepentingan pada perusahaan. Perusahaan biasanya mengalami kesulitan untuk memutuskan apakah akan membagi dividen atau menahan laba untuk diinvestasikan kembali kepada proyek-proyek yang menguntungkan guna meningkatkan pertumbuhan perusahaan. Apabila perusahaan memilih untuk membagikan laba dalam bentuk dividen yang lebih besar, maka jumlah laba ditahan akan semakin kecil sehingga mengurangi jumlah sumber dana internal (Djumahir, 2009). Kebijakan dividen pada perusahaan yang go public mempunyai dampak yang sangat penting bagi para investor maupun bagi perusahaan. Pada umumnya para investor mempunyai tujuan utama untuk meningkatkan kesejahteraannya yaitu mengharapkan keuntungan atas investasinya dalam bentuk dividen maupun capital gain. Di pihak lain, perusahaan juga mengharapkan adanya pertumbuhan secara terus-menerus untuk mempertahankan kelangsungan hidupnya. Manajemen perusahaan harus bisa membuat sebuah kebijakan yang mampu memenuhi kebutuhan dana, sedangkan pihak investor memperoleh apa yang diinginkan, sehingga investor tidak mengalihkan investasinya ke perusahaan lain (Sari, 2010).

Berdasarkan signaling theory, perusahaan membayar dividen untuk memberikan sinyal kepada para investor mengenai keberhasilan perusahaan membukukan profit dan prospek kedepannya. Oleh sebab itu, perusahaan hanya akan meningkatkan pembayaran dividen ketika laba mengalami peningkatan. Dengan kata lain, semakin besar keuntungan yang diperoleh semakin besar 
kemampuan perusahaan untuk membayar dividen. Hal ini menunjukkan bahwa perusahaan akan selalu berusaha untuk meningkatkan citranya dengan meningkatkan porsi laba yang dibagikan sebagai dividen sehingga diharapkan mampu meningkatkan nilai perusahaan (Ariandani dan Yadnyana, 2016). Dividen tidak hanya ditentukan dari laba bersih, namun yang lebih penting adalah profitabilitas perusahaan. Profitabilitas menjadi faktor penting dalam mempengaruhi kebijakan dividen (Badu, 2013 dalam Ariandani dan Yadnyana, 2016).

Penelitian yang dilakukan Al-Taleb (2012), Ahmad dan Wardani (2014), Ahmed dan Murtaza (2015), Awad (2015), Wasike dan Ambrose (2015), Bushra dan Mirza (2015) serta Elmi dan Muturi (2016) menemukan bahwa profitabilitas berpengaruh positif pada kebijakan dividen. Hasil yang bertentang diperoleh Sanjari dan Zarei (2015), Hammed (2015), serta Maladjian dan Khoury (2015) yang menyatakan bahwa profitabilitas tidak berpengaruh pada kebijakan dividen.

Masalah kebijakan dividen berkaitan dengan masalah keagenan. Masalah keagenan timbul karena dipicu oleh tindakan opportunistic para manajer (agent) yang bertujuan untuk memakmurkan dirinya sendiri dan bukan untuk memaksimalkan nilai perusahaan (Pujiati, 2015). Tindakan manajer ini bertentangan dengan kepentingan para pemegang saham (principal) yang menginginkan keuntungan maksimum, sehingga muncul konflik keagenan. Konflik keagenan yang terjadi antara manajer dan pemegang saham dapat diminimumkan dengan suatu mekanisme pengawasan. Namun, munculnya 
Ni Wayan Yunisari dan Ni Made Dwi Ratnadi. Pengaruh...

mekanisme pengawasan tersebut akan menimbulkan biaya bagi para pemegang saham yaitu biaya keagenan atau agency cost (Jensen dan Meckling, 1976).

Salah satu cara mengurangi agency cost dengan memberikan kesempatan pada manajer untuk terlibat dalam kepemilikan saham. Hal ini dilakukan untuk menyetarakan antara kepentingan manajer dan pemegang saham. Keterlibatan manajer tersebut mendorong manajer untuk bertindak secara hati-hati karena mereka akan turut menanggung konsekuensi atas keputusan yang diambilnya. Selain itu, manajer akan termotivasi untuk meningkatkan kinerjanya dalam mengelola perusahaan (Dewi, 2008). Kepemilikan manajerial merupakan salah satu aspek corporate governance yang dapat mengurangi timbulnya agency cost apabila porsinya dalam struktur kepemilikan di perusahaan ditingkatkan (Pujiati, 2015).

Manajer yang memiliki saham dalam perusahaan yang dipimpin akan mempunyai peran ganda yaitu sebagai manajer sekaligus sebagai investor. Posisi manajer sebagai investor tentunya lebih menyukai pendapatan dividen yang besar (bird in the hand theory). Keterlibatan manajer dalam kepemilikan saham sebuah perusahaan menyebabkan aset yang dimiliki tidak terdiversifikasi secara optimal dan sebagai kompensasinya, manajer cenderung menginginkan dividen yang tinggi (Nuringsih, 2005). Kepemilikan manajerial yang makin tinggi memungkinkan perusahaan membayar dividen dalam jumlah yang rendah karena sumber dana internal lebih efisien dibandingkan dengan sumber daya eksternal. Sebaliknya, pada tingkat kepemilikan manajerial yang rendah memungkinkan 
perusahaan membagikan dividen dalam jumlah yang besar dengan tujuan untuk menarik investor (Devi, 2014).

Penelitian yang dilakukan Vo dan Nguyen (2014), Huda dan Abdullah (2014) serta Arifin (2015) menemukan bahwa kepemilikan manajerial berpengaruh positif pada kebijakan dividen. Hal ini bertentangan dengan penelitian yang dilakukan Setiawan dan Mertha (2012), Yudiana dan Yadnyana (2016) yang menemukan bahwa kepemilikan manajerial tidak berpengaruh pada kebijakan dividen. Penelitian yang dilakukan Dewi (2008) menemukan bahwa kepemilikan manajerial berpengaruh negatif pada kebijakan dividen. Hal ini sejalan dengan penelitian Mollah et.al (2000), Ullah (2014), Tarmizi dan Agnes (2016) serta Sari dan Budiasih (2016) yang menemukan bahwa kepemilikan manajerial berpengaruh negatif pada kebijakan dividen.

Teori agensi menyatakan bahwa adanya konflik yang terjadi antara manajemen dan pemegang saham membuat masing - masing pihak berkeinginan untuk memegang kas yang ada di perusahaan. Perusahaan yang memiliki arus kas bebas yang tinggi akan lebih berpeluang untuk membagikan dividen. Likuiditas perusahaan merupakan faktor penting yang harus dipertimbangkan dalam pengambilan keputusan untuk menetapkan jumlah dividen yang akan dibagikan pada pemegang saham (Susanto, dkk. 2013). Dividen merupakan cash outflow, semakin kuat posisi kas dan likuiditas perusahaan maka makin besar pula kemampuan suatu perusahaan dalam memperoleh keuntungan (Sutrisno, 2001). Bagi perusahaan yang memiliki laba ditahan yang cukup, tetapi manajemen 
Ni Wayan Yunisari dan Ni Made Dwi Ratnadi. Pengaruh...

memutuskan untuk menginvestasikan ke dalam aktiva riil, maka perusahaan tidak dapat membayar dividen dalam bentuk kas.

Berdasarkan uraian hasil penelitian yang telah dikemukakan di atas, masih ditemukan adanya perbedaan hasil penelitian dari para peneliti sebelumnya. Perbedaan hasil penelitian tersebut terjadi mungkin karena adanya perbedaan sampel penelitian serta adanya faktor-faktor lain di luar model penelitian yang dapat mempengaruhi kebijakan dividen. Hal tersebutlah yang memotivasi peneliti untuk kembali meneliti mengenai pengaruh profitabilitas dan kepemilikan manajerial pada kebijakan dividen dengan menambahkan variabel likuiditas sebagai variabel moderasi. Pemilihan likuiditas sebagai variabel moderasi bermaksud untuk menguji apakah likuiditas memperkuat atau memperlemah pengaruh profitabilitas dan kepemilikan manajerial terhadap kebijakan dividen, karena hanya perusahaan yang memiliki tingkat likuiditas baik yang akan membagikan labanya dalam bentuk dividen (Suharli, 2007).

Tujuan dalam penelitian ini adalah untuk menguji secara empiris pengaruh profitabilitas pada kebijakan dividen, untuk menguji secara empiris pengaruh kepemilikan manajerial pada kebijakan dividen, untuk menguji secara empiris kemampuan likuiditas memoderasi pengaruh profitabilitas pada kebijakan dividen dan untuk menguji secara empiris kemampuan likuiditas memoderasi pengaruh kepemilikan manajerial pada kebijakan dividen.

Kegunaan penelitian ini adalah sebagai teoritis penelitian ini dapat memberikan kontribusi tambahan pengetahuan terkait dengan signaling theory dan agency theory untuk menjelaskan kebijakan dividen dan sebagai praktis hasil 
penelitian ini dapat memberikan informasi yang dapat dijadikan pertimbangan bagi investor, kreditur, dan pemerintah ketika akan melakukan pengambilan keputusan mengenai investasi. Serta hasil penelitian ini diharapkan dapat menjadi bahan referensi serta bahan pertimbangan bagi peneliti selanjutnya yang akan melakukan penelitian mengenai kebijakan dividen.

Kebijakan dividen tidak dapat dipisahkan dari profitabilitas suatu perusahaan karena pembagian dividen bergantung pada jumlah laba yang mampu dicapai perusahaan. Peningkatan laba bersih akan meningkatkan tingkat pengembalian bagi investasi berupa pendapatan dividen bagi investor. Penelitian yang dilakukan Yudiana dan Yadnyana (2016) menemukan bahwa profitabilitas berpengaruh positif pada kebijakan dividen. Hasil penelitian tersebut menyatakan bahwa semakin tinggi profitabilitas suatu perusahaan semakin besar jumlah dividen yang akan dibagikan. Hasil penelitian tersebut sejalan dengan penelitian yang dilakukan Devi dan Suardikha (2014), Awad (2015), serta Elmi dan Muturi (2016) menemukan bahwa profitabilitas berpengaruh positif pada kebijakan dividen.

Signaling theory dijelaskan bahwa informasi tentang dividen yang dibayarkan dianggap sebagai sinyal mengenai prospek perusahaan dimasa mendatang oleh investor. Peningkatan pembayaran dividen akan dianggap sebagai sinyal positif yang menggambarkan bila perusahaan memiliki prospek yang baik, sehingga menimbulkan reaksi harga saham yang positif (Hastuti, 2013 dalam Ariandani dan Yadnyana, 2016). Perusahaan yang memiliki stabilitas keuntungan dapat menetapkan tingkat pengambilan dividen dengan yakin dan mensinyalkan 
Ni Wayan Yunisari dan Ni Made Dwi Ratnadi. Pengaruh...

kualitas atas keuntungan mereka. Berdasarkan alasan tersebut, hipotesis yang dapat dikembangkan dalam penelitian ini adalah :

$\mathrm{H}_{1}$ : Profitabilitas berpengaruh positif pada kebijakan dividen.

Teori keagenan menyatakan bahwa perusahaan yang memisahkan fungsi pengelolaan dengan fungsi kepemilikan akan rentan terhadap konflik keagenan. Manajer memiliki kecenderungan untuk berperilaku konsumtif dan oportunistik karena mereka menerima keuntungan secara penuh dan sedikit menanggung biaya dari kegiatan tersebut. Prosedur pengawasan dibutuhkan untuk meminimalisir konflik keagenan yang terjadi (Dewi, 2008). Adanya kepemilikan manajerial dapat meminimalisir biaya agensi yang timbul dari adanya konflik keagenan. Penelitian yang dilakukan oleh Ullah (2014) menyatakan bahwa kepemilikan manajerial berpengaruh negatif pada kebijakan dividen perusahaan. Hasil penelitian tersebut sejalan dengan penelitian yang dilakukan oleh Mollah, et.al (2000), Dewi (2008), Andriyani (2008), serta Sari dan Budiasih (2016) yang menemukan bahwa kepemilikan manajerial berpengaruh negatif pada kebijakan dividen.

Pada tingkat kepemilikan manajerial yang tinggi, manajer akan mengalokasikan laba perusahaan pada laba ditahan daripada pembayaran dividen dengan alasan sumber dana internal lebih efisien dibanding sumber dana eksternal (Pujiati, 2015). Penetapan dividen yang rendah akan membuat perusahaan memiliki laba ditahan yang tinggi sehingga perusahaan akan memiliki sumber dana internal yang relatif tinggi untuk membiayai kegiatan investasi di masa depan. Dengan adanya keterlibatan manajer dalam kepemilikan perusahaan akan 
membuat manajer bertindak berhati-hati dalam pengambilan keputusan karena mereka ikut menanggung konsekuensi atas keputusan yang diambil (Nuringsih, 2005). Semakin tinggi kepemilikan manajerial dalam suatu perusahaan, maka semakin rendah jumlah dividen yang dibagikan karena perusahaan dengan kepemilikan manajerial yang tinggi cenderung mengalokasikan laba yang diperolehnya pada laba ditahan dibandingkan membagikannya dalam bentuk dividen (Dewi, 2008).

$\mathrm{H}_{2}$ : Kepemilikan manajerial berpengaruh negatif pada kebijakan dividen.

Likuiditas menunjukkan kemampuan perusahaan di dalam melunasi kewajiban jangka pendeknya. Likuiditas menjadi salah satu pertimbangan manajer ketika memutuskan untuk membayarkan dividen. Perusahaan yang memiliki likuiditas baik akan mampu memenuhi kewajiban jangka pendeknya salah satunya yaitu melakukan pembayaran dividen. Meskipun perusahaan dapat memperoleh laba yang tinggi namun apabila posisi likuiditas menunjukkan keadaan yang tidak begitu baik, perusahaan mungkin tidak akan membagikan dividennya (Suharli, 2007). Kondisi tersebut terjadi karena laba yang diperoleh perusahaan pada periode tersebut digunakan untuk memperbaiki posisi likuiditas perusahaan.

Penelitian mengenai hubungan profitabilitas dengan kebijakan dividen telah banyak dilakukan. Penelitian yang dilakukan Awad (2015), Yudiana dan Yadnyana (2016), serta Sari dan Budiasih (2016) menyatakan bahwa profitabilitas berpengaruh positif pada kebijakan dividen. Hasil yang bertentangan ditunjukkan pada penelitian Nuringsih (2005), Sanjari dan Zarei (2015) serta Maladjian dan 
Ni Wayan Yunisari dan Ni Made Dwi Ratnadi. Pengaruh...

Khoury (2015) yang menyatakan bahwa profitabilitas berpengaruh negatif pada kebijakan dividen.

Hanya perusahaan yang memiliki likuiditas yang baik yang akan membagikan dividen kepada pemegang saham dalam bentuk tunai (Suharli, 2007). Dividen merupakan arus kas keluar sehingga apabila profitabilitas perusahaan meningkat dengan likuiditas perusahaan yang semakin tinggi maka semakin besar jumlah dividen yang akan dibagikan. Kas yang memadai belum tentu dimiliki oleh perusahaan dengan laba yang tinggi, sehingga apabila perusahaan ingin membagikan dividen maka perusahaan perlu memiliki kas yang cukup karena dividen umumnya dibagikan dalam bentuk dividen kas (Darminto, 2008). Berdasarkan alasan tersebut, hipotesis yang dapat dikembangkan dalam penelitian ini adalah :

$\mathrm{H}_{3}$ : Likuiditas memperkuat pengaruh profitabilitas pada kebijakan dividen.

Free cash flow theory menyatakan bahwa semakin tinggi arus kas bebas yang dimiliki perusahaan maka semakin tinggi kemungkinan munculnya konflik keagenan (Opler et al., 1999). Konflik keagenan dapat diminimalisir dengan prosedur pengawasan yang menimbulkan adanya biaya agensi. Kepemilikan manajerial akan mengurangi biaya agensi yang timbul pada perusahaan. Penelitian yang dilakukan oleh Stouraitis dan Wu (2004) serta Nuringsih (2005) menunjukkan bahwa kepemilikan manajerial berpengaruh positif pada kebijakan dividen. Semakin besar keterlibatan manajer dalam managerial ownership menyebabkan aset yang dimiliki tidak terdiversifikasi secara optimal sehingga manajer menginginkan dividen yang semakin besar (Nuringsih, 2005). Hasil yang 
bertentangan ditemukan oleh Mollah, et.al (2000), Dewi (2008), dan Andriyani (2008) yang menyatakan bahwa kepemilikan manajerial berpengaruh negatif pada kebijakan dividen. Pada tingkat kepemilikan manajerial yang semakin tinggi, pihak manajemen yang juga sebagai bagian dari pemilik perusahaan memandang bahwa laba yang dihasilkan perusahan lebih baik untuk dinvestasikan karena memiliki profit yang besar dan dapat menguntungkan perusahaan (Sari dan Budiasih, 2016).

Pada tingkat kepemilikan manajerial yang tinggi, manajer mengalokasikan laba pada laba ditahan daripada pembayaran dividen dengan alasan sumber dana internal lebih efisien dibanding sumber dana eksternal (Nuringsih, 2005). Penetapan dividen yang rendah akan membuat perusahaan memiliki laba ditahan yang tinggi sehingga memiliki sumber dana internal yang relatif tinggi untuk membiayai investasi di masa mendatang. Pihak manajemen perusahaan akan menggunakan potensi likuiditas yang ada untuk melunasi utang atau mendanai operasi perusahaan. Manajer akan melakukan tindakan yang terbaik bagi perusahaan dengan menahan laba bersih untuk menunjang pertumbuhan perusahaan. Berdasarkan alasan tersebut.

$\mathrm{H}_{4}$ : Likuiditas memperkuat pengaruh kepemilikan manajerial pada kebijakan dividen.

\section{METODE PENELITIAN}

Penelitian ini menggunakan pendekatan kuantitatif yang berbentuk penelitian asosiatif dengan tipe kausalitas. Penelitian asosiatif adalah penelitan yang bertujuan untuk mengetahui hubungan antara dua variabel atau lebih. Objek pada 
Ni Wayan Yunisari dan Ni Made Dwi Ratnadi. Pengaruh...

penelitian ini adalah kebijakan dividen yang dijelaskan dengan profitabilitas dan kepemilikan manajerial.

Variabel dependen yang peneliti gunakan dalam penelitian ini adalah kebijakan dividen. Variabel independen pada penelitian ini terdiri atas profitabilitas dan kepemilikan manajerial selanjutnya variabel moderasi dalam penelitian ini adalah likuiditas.

Populasi dari penelitian ini adalah perusahaan manufaktur yang terdaftar di Bursa Efek Indonesia pada periode 2012 sampai 2016. Perusahaan manufaktur dipilih sebagai populasi penelitian karena industri manufaktur mempunyai kontribusi besar terhadap pertumbuhan ekonomi Indonesia. Dengan kontribusi hampir mencapai 17,8 persen terhadap Produk Domestik Bruto (PDB) nasional, industri manufaktur merupakan sektor utama pendorong pertumbuhan ekonomi (www.kemenperin.go.id). Penggunaan lima periode dilakukan untuk melihat konsistensi pengaruh variabel independen terhadap variabel dependen baik disertai atau tanpa disertai variabel moderasi.

Metode pengambilan sampel yang digunakan adalah metode non probability sampling dengan teknik purposive sampling. Metode purposive sampling adalah yaitu metode pemilihan sampel yang didasarkan pada beberapa kriteria tertentu. Kriteria yang digunakan dalam menentukan sampel pada penelitian ini adalah perusahaan manufaktur di Bursa Efek Indonesia yang membagikan dividen pada tahun 2012-2016.

Metode pengumpulan data pada penelitian ini adalah metode observasi non partisipan, yaitu teknik pengumpulan data di mana peneliti tidak terlibat 
secara langsung dan hanya sebagai pengamat independen (Sugiyono, 2014:204). Data yang dipergunakan adalah data laporan keuangan tahunan perusahaan manufaktur yang dipublikasikan pada situs Bursa Efek Indonesia (www.idx.co.id).

Data kuantitatif yang digunakan dalam penelitian ini adalah nilai dividend per share, earning per share, persentase saham milik manajerial, total saham perusahaan, total kas dan setara kas, return on asset serta total hutang lancar pada laporan keuangan perusahaan manufaktur yang terdaftar di Bursa Efek Indonesia periode 2012-2016. Penelitian ini menggunakan data sekunder, yaitu data yang tidak diperoleh dari sumbernya langsung tetapi diperoleh dari sumber-sumber lain, misalnya melalui dokumen. Data yang digunakan dalam penelitian ini bersumber dari Bursa Efek Indonesia (BEI) yang diterbitkan dan diperoleh melalui situs resmi BEI yang mempublikasikan laporan keuangan, baik di Annual Report maupun laporan ringkasan kerja perusahaan.

Teknik analisis data yang digunakan adalah Moderated Regression Analysis (MRA). MRA merupakan aplikasi khusus regresi linier berganda, yang dalam persamaan regresinya mengandung unsur interaksi atau perkalian antara dua atau lebih variabel independen (Utama, 2012:143). Data dianalisis dengan bantuan program Statistical Package for Social Science (SPSS). Persamaan regresi seperti berikut ini.

$Y=\alpha+\beta_{1} X_{1}+\beta_{2} X_{2}+\beta_{3} X_{3}+\beta_{4} X_{1} * X_{3}+\beta_{5} X_{2} * X_{3}+$ e.

Keterangan

Y

$\mathrm{X}_{1}$

: Kebijakan Dividen

: Profitabilitas

$\mathrm{X}_{2} \quad$ : Kepemilikan Manajerial 


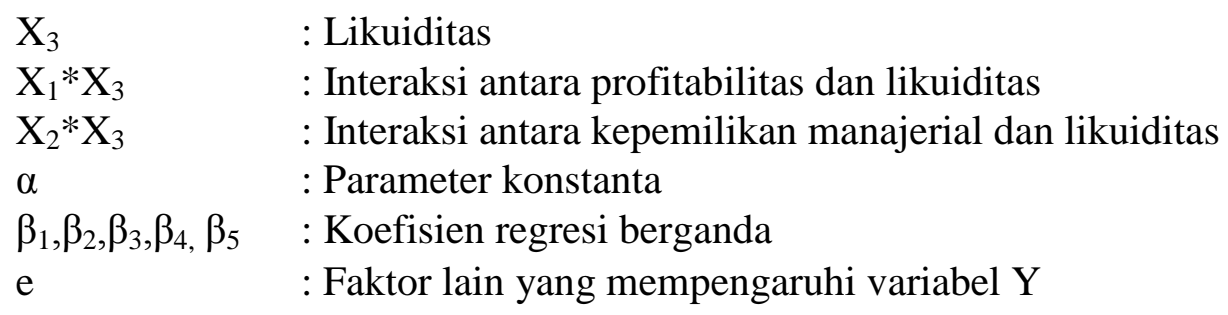

\section{HASIL DAN PEMBAHASAN}

Analisis statistik deskriptif memberikan informasi mengenai karakteristik variabel-variabel penelitian yang terdiri atas jumlah pengamatan, nilai minimum, nilai maksimum, nilai rata-rata, dan deviasi standar. Tabel 1. memperlihatkan hasil uji statistik deskriptif.

Tabel 1.

Hasil Uji Statistik Deskriptif

\begin{tabular}{lrrrrr}
\hline & N & Minimum & Maximum & \multicolumn{1}{c}{ Mean } & Std. Deviation \\
\hline Kebijakan Dividen & 193 & 0,070 & 145,920 & 35,767 & 26,045 \\
Profitabilitas & 193 & 0,570 & 65,720 & 10,689 & 9,270 \\
Kepemilikan Manajerial & 193 & 0,000 & 27,770 & 0,553 & 2,737 \\
Likuiditas & 193 & 0,479 & 1142,662 & 83,764 & 157,504 \\
Valid N (listwise) & 193 & & & &
\end{tabular}

Kebijakan dividen dalam penelitian ini diukur dengan Dividend Payout Ratio. Kebijakan dividen memiliki nilai minimum sebesar 0,070 persen dan nilai maksimum sebesar 145,920 persen. Nilai rata-rata kebijakan dividen sebesar 35,767 mempunyai arti bahwa nilai rata-rata dividend per share dalam suatu perusahaan sebesar 35,767 persen dari earning per share perusahaan. Nilai deviasi standar kebijakan dividen sebesar 26,045 menunjukkan bahwa terjadi perbedaan nilai kebijakan dividen yang diteliti terhadap nilai rata-ratanya sebesar 26,045 persen. 
Profitabilitas memiliki nilai minimum sebesar 0,570 persen dan nilai maksimum sebesar 65,720 persen. Nilai rata-rata profitabilitas sebesar 10,689 mempunyai arti bahwa nilai rata-rata laba bersih dalam suatu perusahaan sebesar 10,689 persen dari total asetnya. Nilai deviasi standar profitabilitas sebesar 9,270 menunjukkan bahwa terjadi perbedaan nilai profitabilitas yang diteliti terhadap nilai rata-ratanya sebesar 9,270 persen.

Kepemilikan manajerial memiliki nilai minimum sebesar 0,000 persen dan nilai maksimum sebesar 27,770 persen. Nilai rata-rata kepemilikan manajerial sebesar 0,553 mempunyai arti bahwa rata-rata total saham yang dimiliki oleh dewan komisaris dan direksi di dalam suatu perusahaan sebesar 0,553 persen dari jumlah saham yang beredar. Nilai deviasi standar kepemilikan manajerial sebesar 2,737 menunjukkan bahwa terjadi perbedaan nilai kepemilikan manajerial yang diteliti terhadap nilai rata-ratanya sebesar 2,737 persen. Likuiditas memiliki nilai minimum sebesar 0,497 persen dan nilai maksimum sebesar 1.142,662 persen. Nilai rata-rata likuiditas sebesar 83,764 mempunyai arti bahwa rata-rata kas dan setara kas di dalam suatu perusahaan sebesar 83,764 persen dari total hutang lancarnya. Nilai deviasi standar likuiditas sebesar 157,504 menunjukkan bahwa terjadi perbedaan nilai likuiditas yang diteliti terhadap nilai rata-ratanya sebesar 157,504 persen.

Uji normalitas bertujuan untuk menguji apakah dalam residual dari model regresi yang dibuat berdistribusi normal. Model regresi yang baik adalah memiliki distribusi residual yang normal atau mendekati normal (Utama, 2014: 99). Suatu model regresi dikatakan memiliki data normal atau mendekati normal apabila 
Ni Wayan Yunisari dan Ni Made Dwi Ratnadi. Pengaruh...

koefisien Asymp.sig (2-tailed) $>\alpha=0,05$. Uji normalitas dilakukan dengan uji Kolmogorov-Smirnov. Hasil uji Kolmogorov-Smirnov dapat dilihat pada Tabel 2. sebagai berikut:

Berdasarkan Uji normalitas nilai Asymp.sig (2-tailed) sebesar 0,186 > 0,05 menunjukkan bahwa data berdistribusi normal sehingga asumsi normalitas sudah terpenuhi. Uji Autokorelasi bertujuan untuk menguji apakah dalam model regresi terdapat korelasi antara kesalahan penggangu pada periode $\mathrm{t}$ dengan kesalahan penggangu pada periode t-1 (sebelumnya). Autokorelasi muncul karena observasi yang berurutan sepanjang waktu berkaitan satu sama lain (Ghozali, 2013:110). Untuk mendeteksi ada tidaknya autokorelasi pada penelitian ini digunakan uji Durbin-Watson (DW-test). Hasil uji autokorelasi pada Lampiran 5 menunjukkan nilai DW sebesar 1,954. Jumlah data $(n)=193$ dan jumlah variabel bebas $(\mathrm{k})=2$ serta $\alpha=5 \%$ diperoleh angka $\mathrm{dl}=1,743$ dan $\mathrm{du}=1,785$. Berdasarkan angka tersebut, maka nilai 4-du = 2,215 (4-1,785). Oleh karena nilai $\mathrm{DW}=1,954$ lebih besar dari $\mathrm{du}=1,785$ dan $\mathrm{DW}=1,954$ kurang dari 4 -du $=$ 2,215 atau $1,785<1,954<2,215$ dapat disimpulkan bahwa tidak terdapat autokorelasi.

Uji heteroskedastisitas bertujuan menguji apakah dalam model regresi terjadi ketidaksamaan variance dari residual satu pengamatan ke pengamatan yang lain. Uji heteroskedastisitas pada penelitian ini dialisis melalui uji glejser dengan melihat tingkat signifikansi. Apabila tingkat signifikansi di atas 0,05 maka model regresi bebas dari heteroskedastisitas. Berdasarkan uji heteroskedastisitas 
nilai signifikansi seluruh variabel lebih besar dari 0,05 yang berarti tidak terdapat pengaruh antara variabel bebas terhadap absolute residual. Dengan demikian, model yang dibuat tidak mengandung gejala heteroskedastisitas.

Berdasarkan uji asumsi klasik, diketahui bahwa data dalam penelitian ini terdistribusi dengan normal, tidak ada autokorelasi dan tidak terjadi heteroskedastisitas. Dengan demikian maka data yang tersedia telah memenuhi syarat untuk menggunakan model Moderated Regression Analysis dengan hasil sebagai berikut.

Tabel 2.

Hasil Uji Regresi (Moderated Regression Analysis)

\begin{tabular}{|c|c|c|c|c|c|c|}
\hline & \multirow[t]{2}{*}{ Model } & $\begin{array}{r}\text { Uns } \\
\text { C }\end{array}$ & $\begin{array}{l}\text { dardized } \\
\text { icients }\end{array}$ & \multirow{2}{*}{$\begin{array}{c}\text { Standardized } \\
\text { Coefficients } \\
\text { Beta } \\
\end{array}$} & \multirow[t]{2}{*}{$\mathbf{t}$} & \multirow[t]{2}{*}{ Sig. } \\
\hline & & $\boldsymbol{\beta}$ & Std. Error & & & \\
\hline \multirow[t]{10}{*}{ l } & (Constant) & 26,604 & 2,938 & & 9,056 & 0,000 \\
\hline & Profitabilitas & 0,990 & 0,210 & 0,353 & 4,709 & 0,000 \\
\hline & Kepemilikan Manajerial & $-0,304$ & 0,753 & $-0,032$ & $-0,403$ & 0,687 \\
\hline & Likuiditas & $-0,026$ & 0,022 & $-0,156$ & $-1,152$ & 0,251 \\
\hline & Profitabilitas*Likuiditas & 0,001 & 0,002 & 0,103 & 0,732 & 0,465 \\
\hline & Kepemilikan & $-0,020$ & 0,015 & $-0,108$ & $-1,358$ & 0,176 \\
\hline & Manajerial*Likuiditas & & & & & \\
\hline & Adjusted $\mathrm{R}^{2}=0,144$ & & & & & \\
\hline & F Hitung $=7,443$ & & & & & \\
\hline & Signifikansi $F=0,000$ & & & & & \\
\hline
\end{tabular}

Berdasarkan Tabel 2, nilai adjusted $\mathrm{R}^{2}$ sebesar 0,144. Artinya sebesar 14,4 persen dari variansi kebijakan dividen perusahaan manufaktur yang terdaftar di Bursa Efek Indonesia tahun 2012-2016 dijelaskan oleh variansi profitabilitas, kepemilikan manajerial, dan likuiditas sedangkan 85,6 persen dipengaruhi oleh variansi faktor-faktor lain diluar penelitian.

Nilai sig $F_{\text {hitung }}=0,000<\alpha=0,05$. Hal ini menunjukkan bahwa model yang digunakan fit atau layak digunakan serta menunjukkan adanya pengaruh profitabilitas dan kepemilikan manajerial pada kebijakan dividen dengan 
Ni Wayan Yunisari dan Ni Made Dwi Ratnadi. Pengaruh...

likuiditas sebagai variabel moderasi. Persamaan regresi yang dapat disusun berdasarkan Tabel 2 adalah sebagai berikut.

$Y=26,604+0,990 X_{1}-0,304 X_{2}-0,026 X_{3}+0,010 X_{1} * X_{3}-0,020 X 2 * X_{3}$

Nilai konstanta $(\alpha)$ sebesar 26,604 memiliki arti apabila variabel profitabilitas, kepemilikan manajerial, interaksi antara variabel profitabilitas dan likuiditas, dan interaksi antara variabel kepemilikan manajerial dan likuiditas konstan, maka dividen per lembar saham sebesar 26,604 persen dari laba per lembar saham.

Nilai $p$-value untuk variabel profitabilitas sebesar $0,000<\alpha=0,05$ dengan nilai koefisien regresi $\left(\beta_{1}\right)$ sebesar 0,990. Hasil ini menunjukkan bahwa profitabilitas berpengaruh signifikan pada kebijakan dividen. Dengan demikian maka $\mathrm{H}_{1}$ diterima. Nilai koefisien regresi profitabilitas $\left(\beta_{1}\right)$ sebesar 0,990 artinya apabila profitabilitas meningkat sebesar satu persen dengan asumsi variabel lainnya konstan, maka kebijakan dividen akan meningkat sebesar 0,990 persen. Nilai $p$-value untuk variabel kepemilikan manajerial sebesar $0,687>\alpha=0,05$ dan koefisien regresi $\left(\beta_{2}\right)$ sebesar -0,304. Hasil ini menunjukkan bahwa kepemilikan manajerial tidak berpengaruh signifikan pada kebijakan dividen. Dengan demikian maka $\mathrm{H}_{2}$ ditolak.

Nilai $p$-value untuk variabel moderasi sebesar $0,465>\alpha=0,05$ dengan koefisien regresi $\left(\beta_{3}\right)$ sebesar 0,010 . Hasil ini menunjukkan bahwa likuiditas tidak mampu memoderasi pengaruh profitabilitas pada kebijakan dividen. Dengan demikian maka $\mathrm{H}_{3}$ ditolak. Nilai $p$-value untuk variabel moderasi sebesar 0,176> $\alpha=0,05$ dengan koefisien regresi $\left(\beta_{4}\right)$ sebesar 0,020 . Hasil ini menunjukkan 
bahwa likuiditas tidak mampu memoderasi pengaruh kepemilikan manajerial pada kebijakan dividen. Dengan demikian maka $\mathrm{H}_{4}$ ditolak.

Hipotesis pertama menyatakan profitabilitas berpengaruh positif pada kebijakan dividen. Hasil analisis menunjukkan profitabilitas berpengaruh pada kebijakan dividen. Arah koefisien profitabilitas dalam penelitian ini bertanda positif yang berarti bahwa semakin besar profitabilitas suatu perusahaan maka kebijakan dividen atau dividend payout ratio akan semakin meningkat. Dengan demikian maka hipotesis pertama diterima.

Penelitian ini mendukung signaling theory yang menyatakan bahwa perusahaan membayar dividen untuk memberikan sinyal kepada para investor mengenai keberhasilan perusahaan membukukan profit dan prospek kedepannya. Oleh sebab itu, perusahaan hanya akan meningkatkan pembayaran dividen ketika laba mengalami peningkatan. Dengan kata lain, semakin besar keuntungan yang diperoleh semakin besar kemampuan perusahaan untuk membayar dividen. Besar kecilnya laba perusahaan akan mempengaruhi jumlah dividen yang dibagikan. Apabila perusahaan mengumumkan peningkatan dividen, maka investor akan menganggap kondisi perusahaan saat ini dan dimasa mendatang relatif baik (Arilaha, 2009).

Hipotesis kedua menyatakan kepemilikan manajerial berpengaruh negatif pada kebijakan dividen. Hasil analisis menunjukkan bahwa kepemilikan manajerial tidak berpengaruh pada kebijakan dividen. Hal ini berarti besar kecilnya persentase kepemilikan manajerial suatu perusahaan tidak mempengaruhi jumlah dividen yang akan dibagikan. Dengan demikian maka hipotesis kedua 
Ni Wayan Yunisari dan Ni Made Dwi Ratnadi. Pengaruh...

ditolak.

Menurut teori keagenan, kepemilikan saham saham oleh manajerial hanya sebatas controlling pemegang saham terhadap kinerja manajemen untuk mengurangi biaya keagenan. Kecilnya persentase kepemilikan saham oleh direksi dan komisaris pada perusahaan menunjukkan bahwa saham yang dimiliki manajerial masih merupakan saham minoritas dibandingkan dengan kelompok pemegang saham lainnya di dalam perusahaan. Hal ini mengakibatkan keputusan dividen banyak ditentukan oleh pemilik saham diluar perusahaan (outsider ownership) karena jumlah saham yang dimiliki oleh manajer relatif kecil (Yudiana dan Yadnyana, 2016).

Hipotesis ketiga menyatakan likuiditas memperkuat pengaruh profitabilitas pada kebijakan dividen. Hasil analisis menunjukkan bahwa likuiditas tidak memoderasi pengaruh profitabilitas pada kebijakan dividen. Hal ini berarti likuiditas tidak mampu meningkatkan pembayaran dividen pada saat profitabilitas tinggi dan likuiditas tidak mampu menurunkan pembayaran dividen pada saat profitabilitas rendah. Dengan demikian maka hipotesis ketiga ditolak.

Berdasarkan teori clientele effect, masing-masing pemegang saham memiliki preferensi yang berbeda terhadap kebijakan dividen. Pemegang saham tidak hanya memperoleh dividen dalam bentuk kas namun dividen dapat dibagikan dalam bentuk saham (stock dividen) dimana tidak semua pemegang saham menginginkan pembagian dividen dalam bentuk kas tetapi terdapat pemegang saham yang menerima apabila dividen dibagikan dalam bentuk non kas (Devi dan Suardikha, 2014). Oleh sebab itu, menurut Devi dan Suardhika (2014), 
keberadaan kas menjadi pertimbangan yang tidak begitu besar di dalam menetapkan dividen yang akan dibayarkan. Ketidaksesuain hasil ini terjadi karena nilai likuiditas terlalu bervariasi dalam jumlah yang signifikan. Berdasarkan data sampel diketahui bahwa besarnya likuiditas berkisar antara 0,479 persen hingga

\section{$1.142,662$ persen.}

Hipotesis keempat menyatakan likuiditas memperkuat pengaruh kepemilikan manajerial pada kebijakan dividen. Hasil analisis menunjukkan bahwa likuiditas tidak memoderasi pengaruh kepemilikan manajerial pada kebijakan dividen. Hal ini berarti likuiditas tidak mampu menurunkan pembayaran dividen pada saat persentase kepemilikan manajerial besar dan likuiditas tidak mampu meningkatkan pembayaran dividen pada saat persentase kepemilikan manajerial kecil. Dengan demikian maka hipotesis keempat ditolak.

Dikaitkan dengan teori keagenan, kepemilikan saham oleh manajerial hanya sebatas controlling pemegang saham terhadap kinerja manajemen untuk mengurangi biaya keagenan. Potensi likuiditas yang ada tidak akan berpengaruh terhadap pengambilan keputusan mengenai dividen karena persentase kepemiikan manajerial pada perusahaan cenderung rendah. Ketidaksesuain hasil ini terjadi karena nilai likuiditas terlalu bervariasi dalam jumlah yang signifikan. Berdasarkan data sampel diketahui bahwa besarnya likuiditas berkisar antara 0,479 persen hingga $1.142,662$ persen.

\section{SIMPULAN}

Berdasarkan hasil analisis dapat disimpulkan bahwa profitabilitas berpengaruh positif pada kebijakan dividen. Hal ini menunjukkan bahwa apabila profitabilitas 
Ni Wayan Yunisari dan Ni Made Dwi Ratnadi. Pengaruh...

semakin meningkat menyebabkan jumlah dividen yang dibayarkan suatu perusahaan akan meningkat. Kepemilikan manajerial tidak berpengaruh pada kebijakan dividen. Hal ini menunjukkan bahwa peningkatan maupun penurunan persentase kepemilikan manajerial tidak mempengaruhi jumlah pembayaran dividen. Likuiditas tidak memoderasi pengaruh profitabilitas pada kebijakan dividen. Hal ini berarti, likuiditas tidak mampu meningkatkan pembayaran dividen pada saat profitabilitas tinggi dan likuiditas tidak mampu menurunkan pembayaran dividen pada saat profitabilitas rendah. Likuiditas tidak memoderasi pengaruh kepemilikan manajerial pada kebijakan dividen. Hal ini berarti, likuiditas tidak mampu menurunkan pembayaran dividen pada saat persentase kepemilikan manajerial besar dan likuiditas tidak mampu meningkatkan pembayaran dividen pada saat persentase kepemilikan manajerial kecil.

Saran yang diberikan dalam penelitian ini untuk peneliti selanjutnya adalah penelitian selanjutnya diharapkan dapat menambah variabel lain seperti investment opportunity set, kepemilikan institusional, free cash flow, dan variabel lainnya, penelitian selanjutnya diharapkan menggunakan variabel moderasi lain karena likuiditas dalam penelitian ini terbukti tidak mampu memoderasi pengaruh profitabilitas pada kebijakan dividen dan kepemilikan manajerial pada kebijakan dividen serta data kepemilikan manajerial pada perusahaan go public masih terbatas sehingga penelitian selanjutnya diharapkan menelusuri data kepemilikan manajerial hingga pada perusahaan privat.

\section{REFERENSI}


Ahmad, G.N., dan Wardani, V.K. (2014). The Effect of Fundamental Factor to Dividend Policy : Evidence in Indonesia Stock Exchange. International Journal of Business and Commerce. 4(2): h: 14-25.

Ahmed, S., dan Murtaza, H. (2015). Critical Analysis of the Factors Affecting the Dividend Payout: Evidence from Pakistan. International Journal of Economics, Finance and Management Sciences. 3(3): h: 204-212.

Al-Taleb, G. (2012). Measurement of Impact Agency Costs Level of Firms on Dividend and Leverage Policy: An Empirical Study. Interdisciplinary Journal Of Contemporary Research In Business. 3(10): h:34-65.

Andriyani, M. (2008). Analisis Pengaruh Cash Ratio, Debt to Equity Ratio, Insider Ownership, Investment Opportunity Set, dan Profitability terhadap Kebijakan Dividen (Studi Empiris pada perusahaan Automotive di Bursa Efek Indonesia Periode tahun 2004-2006). Tesis Program Pasca Sarjana Universitas Diponegoro.

Andriyanti, L., dan Wirakusuma, M. G. (2014). Good Corporate Governance Memoderasi Profitabilitas, Leverage, Arus Kas Bebas dengan Kebijakan Dividen. Skripsi Fakultas Ekonomi dan Bisnis Universitas Udayana

Ariandani, P.S., dan Yadnyana, I. K. (2016). Likuiditas Memoderasi Pengaruh Profitabilitas dan Investment Opportunity Set (IOS) pada Kebijakan Dividen. Jurnal Akuntansi Universitas Udayana, 17(1): h: 615-634.

Arifin, S. (2015). Pengaruh Profitabilitas, Likuiditas, Growth Potential, dan Kepemilikan Manajerial Terhadap Kebijakan Dividen. Skripsi. Sekolah Tinggi Ilmu Ekonomi Indonesia.

Arilaha, M.A. (2009). Pengaruh Free Cash Flow, Profitabilitas, Likuiditas, dan Leverage Terhadap Kebijakan Dividen. Jurnal Keuangan dan Perbankan, 13(1): h: $78-87$

Atmaja, L.S. (2008). Manajemen Keuangan. Yogyakarta : Penerbit Andi,

Awad, B. (2015). Determinants of Dividend Policy in Kuwait Stock Exchange. International Journal of Business and Management Review. 3(7): h: 72-78.

Bhattacharya, S. (1979). Imperfect Information, Dividend Policy, and The Bird in Hand Fallacy. The Bell Journal of Economic, 10(1): h: 259-270.

Brigham, E.F., dan Houston, J. F. (2001). Manajemen Keuangan. Edisi 8. Jakarta: Erlangga. 
Bushra, A., dan Mirza, N. (2015). The Determinants of Corporate Dividend Policy in Pakistan. The Lahore Journal of Economics. 20(2): h: 77-83

Devi, A.A.M.V., dan Suardhika, I.M.S. (2014). Pengaruh Profitabilitas pada Kebijakan Dividen dengan Likuiditas dan Kepemilikan Manajerial sebagai Variabel Pemoderasi. Jurnal Akuntansi Universitas Udayana 3(12): h: 702717.

Devi, N.P.Y. (2014). Pengaruh Kepemilikan Manajeral, Leverage, dan Ukuran Perusahaan pada Kebijakan Dividen Perusahaan Manufaktur. Jurnal Akuntansi Universitas Udayana 9(3): h: 709-716.

Dewi, S.C. (2008). Pengaruh Kepemilikan Managerial, Kepemilikan Institusional, Kebijakan Hutang, Profitabilitas, dan Ukuran Perusahaan Terhadap Kebijakan Dividen. Jurnal Bisnis dan Akuntansi. 10(1): h: 47-58.

Djumahir. (2009). Pengaruh Biaya Agensi, Tahap Daur Hidup Perusahaan, dan Regulasi terhadap Kebijakan Dividen pada Perusahaan Manufaktur di Bursa Efek Indonesia. Jurnal Manajemen dan Kewirausahaan. 11(2): h: 144-153.

Eisenhardt, Kathleen. (1989). Building Theories from Case Study Reserach. The Academy of Management Review, 14(4): pp:532-550.

Elmi, M.A., dan Muturi, W.M. (2016). Effects of Profitability on Dividend Payout by Commercial and Service Firms Listed in The Nairobi Securities Exchange. European Journal of Business and Social Sciences, 5(2): h: 160 16.

Fadhilah, F.N., dan Syafruddin, M. (2013). Analisis Pengaruh Karakteristik Corporate Governance Terhadap Kemungkinan Financial Distress. Diponegoro Journal of Accounting, 2(2): h:1-15.

Ghozali, I. (2013). Aplikasi Analisis Multivariate dengan Program SPSS 19. Edisi ketujuh. Semarang: Badan Penerbit Universitas Diponegoro

Hammed, I.E. (2015). Liquidity, Profitability and the Dividends Payout Policy. World Review of Business Research. 5(2): h: 73-85

Horne, J.C.V., dan John, M. (2012). Financial Management and Policy. Ed 13. Terjemahan Salemba empat. Jakarta

Huda, N., dan Abdullah, M.N. (2014). Relationship between Ownership Structure and Dividend Policy: Empirical Evidence from Chittagong Stock Exchange. World Review of Business Research. 4(3): h: $14-34$ 
Idawati, I.A.A., dan Sudiartha, G.M. (2014). Pengaruh Profitabilitas, Likuiditas, Ukuran Perusahaan terhadap Kebijakan Dividen Perusahaan Manufaktur di BEI. Jurnal Manajemen Universitas Udayana, 3(6)

Jensen, M.C., dan Meckling, W.H. (1976). Theory of the Firm: Managerial Behavior, Agency Costs and Ownership Structure. Journal of Financial Economics. 3(4): h: 305-360.

Kieso, D.E., Jerry J.W., dan Terry D.W. (2002). Akuntansi Intermediet, Edisi 10. Jakarta: Erlangga

Maladjian, C., dan Khoury, R.E. (2014). Determinants of the Dividend Policy: An Empirical Study on the Lebanese Listed Banks. International Journal of Economics and Finance. 6(4).

Mollah, K. dan Short. (2000). The Influence of Agency Cost on Dividend Policy in an Emerging Market Evidence from The Dhaka Stock Exchange. International Journal of Economics. 5: h:249-259.

Nurhayati. (2016). Pengaruh Profitabilitas, Investment Opportunity Set, dan Pertumbuhan Perusahaan Terhadap Kebijakan Dividen. Skripsi Fakultas Ekonomi Universitas Pasundan Bandung

Nuringsih, K. (2005). Analisis Pengaruh Kepemilikan Manajerial, Kebijakan Hutang, ROA dan Ukuran Perusahaan Terhadap Kebijakan Dividen. Jurnal Akuntansi dan Keuangan Indonesia. 2(2): h:103-123

Opler, T., Lee P., Rene S., dan Rohan W. (1999). The Determinants And Implications Of Corporate Cash Holdings. Journal of Financial Economics. 52: h: 3- 46.

Pujiati. (2015). Faktor-Faktor yang Mempengaruhi Kebijakan Dividen Pada Sektor Industri Barang Konsumsi. Jurnal Sarjana Jurusan Akuntansi pada Fakultas Ekonomi Universitas Negeri Yogyakarta, Yogyakarta

Pramastuti, S. (2007). Analisis Kebijakan Dividen : Pengujian Signaling Theory dan Rent Extraction Hypothesis. Tesis Universitas Gajah Mada.

Rahyuda, I.K., Yasa, W.M., dan Yuliarmi, N.N. (2004). Metodologi Penelitian. Diktat Kuliah pada Fakultas Ekonomi dan Bisnis Universitas Udayana.

Ratnadi, N.M.D., Sutrisno T., Achsin., dan Aji D.M. (2013). The Effect of Shareholders Conflict over Dividend Policy on Accounting Conservatism : Evidence From Public Firm in Indonesia. Research Journal of Finance and Accounting. 4(6): h: 146-155 
Sanjari, T. dan Zarei, B. (2015). Studying of Factor Influencing Corporate Dividend Policy of Financial and Non Financial Firms on Companies Listed in Tehran Stock Exchange. Indian Journal of Fundamental and Applied Life Sciences. 5 (S3): h: 718-725.

Sari, N.K.A.P., dan Budiasih, I.G.A.N. (2016). Pengaruh Kepemilikan Managerial, Kepemilikan Institusional, Free Cash Flow dan Profitabilitas pada Kebijakan Dividen. Jurnal Akuntansi Universitas Udayana 15(3): h: 2439-2466.

Sari, F.R. (2010). Analisis Pengaruh Kepemilikan Manajerial, Kebijakan Utang, Profitabilitas, Ukuran Perusahaan, dan Kesempatan Investasi terhadap Kebijakan Dividen. Skripsi Fakultas Ekonomi Universitas Sebelas Maret

Sartono, A. (2010). Manajemen Keuangan Teori dan Aplikasi. Edisi ke 4. Yogyakarta: BPFE

Setiawan, A., dan Mertha, I.M. (2012). Analisis Faktor-Faktor yang Mempengaruhi Kebijakan Dividen pada Perusahaan Wholesale dan Retail Trade di BEI. Jurnal Akuntansi Universitas Udayana, 1(2)

Stouraitis, A., dan Wu, L. (2004). The Impact of Ownership Structure on the Dividend Policy of Japanese Firms with Free Cash Flow Problem. AFFI December meeting.

Sugiyono. (2014). Metode Penelitian Pendidikan Pendekatan Kuantitatif, Kualitatif Dan R\&D. Bandung: Alfabeta.

Suharli. (2007). Pengaruh Profitability dan Invesment Opportunity Set Terhadap Kebijakan Dividen Tunai dengan Likuiditas Sebagai Variabel Penguat, Jurnal Ekomomi Akuntansi, h: 9-17

Susanto, L., Merry S.S., dan Sriwahyuni. (2013). Pengaruh Liquidity, Profitability, Leverage, Size, Collateral Assets, Growth, dan Institutional Ownership Terhadap Dividend Policy Perusahaan Manufaktur yang Terdaftar di BEI. Jurnal Jurusan Akuntansi Fakultas Ekonomi Universitas Tarumanagara, Jakarta. 17(1).

Tarmizi, R., dan Agnes, T. (2016). Pengaruh Kepemilikan Manajerial, Kepemilikan Institusional, Free Cash Flow, dan Profitabilitas Terhadap Kebijakan Dividen Pada Perusahaan Manufaktur Go Public yang Terdaftar di BEI (Periode 2010-2013). Jurnal Akuntansi \& Keuangan. 7(1): h:103 119.

Ulfah, I.F. (2011). Pengaruh Agency Cost, Firm Size, dan Profitability Terhadap Kebijakan Dividen dengan Likuiditas sebagai Variabel Moderasi. Tesis 
Program Studi Magister Akuntasi Fakultas Ekonomi Universitas Sebelas Maret Surakarta.

Ullah, H. (2014). The Impact of Ownership Structure on Dividend Policy Evidence from Emerging Markets KSE-100 Index Pakistan. International Journal of Business and Social Science. 3(9).

Utama, M.S. (2014). Aplikasi Analisis Kuantitatif. Edisi ke-8. Buku Ajar Kuliah pada Fakultas Ekonomi dan Bisnis Universitas Udayana.

Vo, D.H., dan Nguyen,V.T.Y. (2014). Managerial Ownership, Leverage and Dividend Policies: Empirical Evidence from Vietnam's Listed Firms. International Journal of Economics and Finance. 6(5): h: 274-284

Wasike, T., dan Jagongo, A. (2015). Determinants of Dividend Policy Kenya. International Journal of Art and Entrepreneurship. 4(11).

Wiagustini, N.L.P. (2014). Manajemen Keuangan. Denpasar: Udayana University Press

Yudiana, I.G.Y., dan Yadnyana, P. (2016). Pengaruh Kepemilikan Manajerial, Leverage, Investment Oppotunity Set dan Profitabilitas pada Kebijakan Dividen Perusahaan Manufaktur. Jurnal Akuntansi Universitas Udayana 15(1): h:112-141 